\title{
ANCIENT AND MODERN ICONOGRAPHY IN THE CONTEXT OF MONETARY ALLIANCES
}

\begin{abstract}
In ancient times, the presence of identical marking on various poleis coins minted during the same timeframe was often indicative of a political, military or economic link. In some cases the numismatic datum merely confirms information found in literary sources, as in the case of the Achaian League, while in others, coin iconography becomes an important source for historical reconstruction. In this perspective we will analyse cases of Agathoklean coinage and its influence - obvious to us - on Magna Graecia currency of the same time, with particular reference to Locri and stephanephoroi of the second century BC, where - conversely - the laurel wreath does not appear to express alliances of any sort. In recent times, monetary alliances reveal less attention for iconographic aspects, as in the nineteenth-century Latin Monetary Union. Keywords: monetary alliances, iconography, Agathokles, stephanephoroi, Latin Monetary Union
\end{abstract}

\section{Andrea Filocamo}

Mediterranean University of Reggio Calabria andrea.filocamo@unirc.it

DOI: $10.14795 /$ j.v3i4.210

ISSN $2360-266 \mathrm{X}$

ISSN-L 2360 - 266X
$\mathbf{M}$ onetary alliances have been a constant throughout history and become significant every time converging interests persuade different state concepts - city-states or nations - to adopt (or impose on others) coins that are more or less immediately recognizable with the same weight, fineness and type. Ancient history provides proof of more than one such instance: in some cases literary sources document the existence of political alliances within which a common currency was issued, a fact borne out in turn by archaeological and numismatic data; in other cases, we find various poleis that issued coinage with very similar characteristics, in relation to which there is direct or indirect evidence of political, commercial or monetary unions. One case falling within the first group mentioned was the Achaian League: Polybius describes the existence of shared rules and institutions, including the issue of a single currency for military needs, characterized by the League's symbols, flanked by those of each issuing polis ${ }^{1}$. Evidently, there can be no doubt that the alliance was also of a monetary nature, as can be seen even from just a surface examination of coins (see Fig. 1).

The second group includes only presumed alliances and it may be interesting to explore the reasons that led the various poleis to adopt similar types of coins or markings. This article comprises a brief commentary on two examples to ancient coins that are part of the latter, but absolutely different from one another. The first involves Magna Graecia coinage of the Agathoklean age, when a growing number of poleis adopting Syracusan coin symbology; the second concerns issues known as stephanephoroi, in particular in Athens in the second century BC, but also in many other Greek poleis that

\footnotetext{
${ }^{1}$ Pol. 2, 37, 9-11.
} 


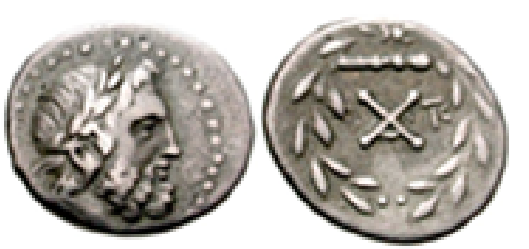

Argos, SHG C op 267

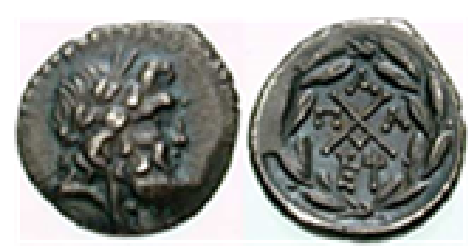

Pallantion, SNG Cop 290

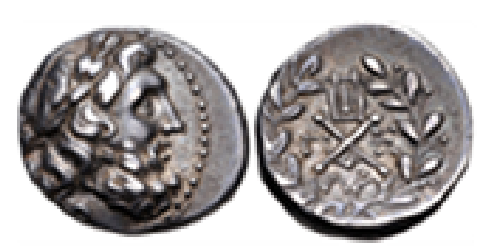

Megara, $\mathrm{HGC} 4,1805$
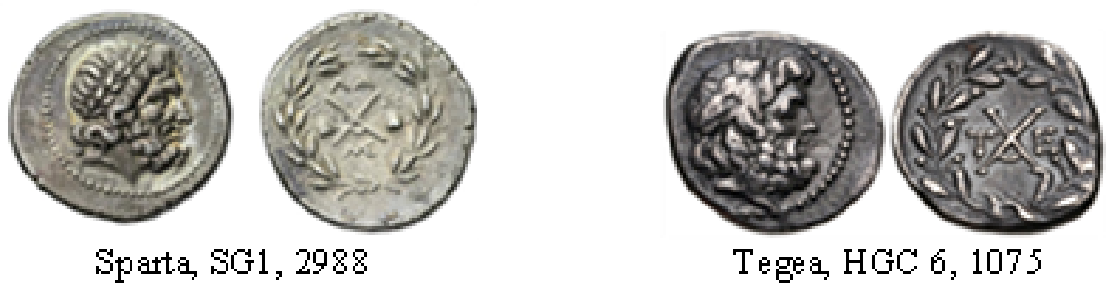

Fig. 1. Examples of coins issued by various cities of the Achaian League. Each coin has the laureate head of Zeus on the obverse and the Achaian League monogram on the reverse, while symbols and letters refer to individual local situations.

encircled the reverse of their coin type with a decorative pattern formed by a foliage crown. As will be seen, as far as we are concerned, the results of interpretation differ and suggest a close political connection between Syracuse and the cities of Magna Graecia in the first instance, while in the second it is more difficult to acknowledge an alliance, even with an economic-trade basis. Nonetheless, the presence of the stephane on the reverse cannot be considered random. Finally, if we are allowed a chronological leap of two thousand years or so, we may examine the role of iconography in the modern world, with reference to another alliance: the Latin Monetary Union of the nineteenth century.

Coinage of the Agathoklean period provides a typical example of how iconography may represent a relevant source for reconstruction of historical events. It has been suitably reiterated ${ }^{2}$ how Magna Graecia was strategically crucial in the plans of Agathokles, not only economically for imports of timber and pitch, but also for control of routes to the Tyrrhenian Sea and the Eastern Mediterranean, as well as in a political-military key, for fear of alliances between the Carthaginians and the Brutti or the Italiots. ${ }^{3}$ The strengthening of the Scylacium-Hipponion hinge was also intended to protect the Strait and the Locri district, mirroring Dionysian policy. Agathokles, as Diodorus wrote, organized military campaigns that allowed him to take control of Crotone and Hipponion ${ }^{4}$.

Fragmented reports by Diodorus may be supplemented with information from numismatic sources, which come mainly but not solely from iconography. Authors like Seltman ${ }^{5}$, but also Regling ${ }^{6}$ and $\mathrm{Hill}^{7}$, and more recently Consolo Langher, ${ }^{8}$ insist that there are type and weight analogies between Syracusan coinage of this period and that of poleis like Hipponion and Terina, but also the more distant

\footnotetext{
2 See CONSOLO LANGHER 2000, 284.

3 For Agathoklean interest in the Adriatic, also see MARASCO 1984, 97-113; BRACCESI 1977, 185; on the possibility of a Bruttian-Punic alliance, see DE SANCTIS 1909, 141-198.

${ }^{4}$ Diod. 21, 4 and 21, 8.

5 SELTMAN 1912, $7 \mathrm{ff}$.

6 REGLING 1906, 55-57.

HILL 1903.

8 CONSOLO LANGHER 2000, 311-314.
}

Metapontum and Velia. Numerous issues by all these poleis reveal similarities with Agathoklean types and symbols, and were coined in compliance with the Syracusan weight system.

For Hipponion - apart from a few staters of Corinthian standard and type ${ }^{9}$ - scholars suggest comparison with the bronze series that shows the head of Athena with Corinthian helmet decorated with serpent, hippocampus or gryphon, and with the legend Soteira on the obverse; on the reverse, a winged Nike with wreath and sceptre. Indeed, the obverse type is directly connected to the Agathoklean silver pegasus and the legend is also of Syracusan derivation. Similarly, the Nike is a typically Agathoklean image ${ }^{10}$ (see Fig. 2). From sources we know that Agathokles took Hipponion in about 295 BC, but lost it soon after. ${ }^{11}$ Nevertheless, construction of a port at Hipponion, undertaken precisely by Agathokles himself, proves his control for a period of time long enough to justify the issue of coins reproducing Agathoklean types and symbols. ${ }^{12}$ Dating between 295 and 289 BC (the year the basileus died) is incontrovertible because of the presence of Agathoklean types and the legend ${ }^{13}$.

While coin iconography confirms for Hipponion what we know with regard to Agathokles' relationship with the polis, the situation is different for Terina, Metapontum and Velia, in relation to which there is no mention in the written sources that attest to Agathoklean influence on them, so the iconographic datum should be approached with more caution.

Consolo Langher ${ }^{14}$ notes how Terina began to mint small silver coins at the end of the fourth century, with a female head on the obverse accompanied by the triskeles, a symbol typical of most Agathoklean issue. This began to represent the identity of Sicily off the island precisely after

\footnotetext{
9 The pegasus is attributed to Hipponium due to the presence of the caduceus. See TALIERCIO MENSITIERI 1993, 131-186; RUTTER 2001, 175-176. According to TROXELL 1975, Pl. 14-15, the series is attributed to Locri. 

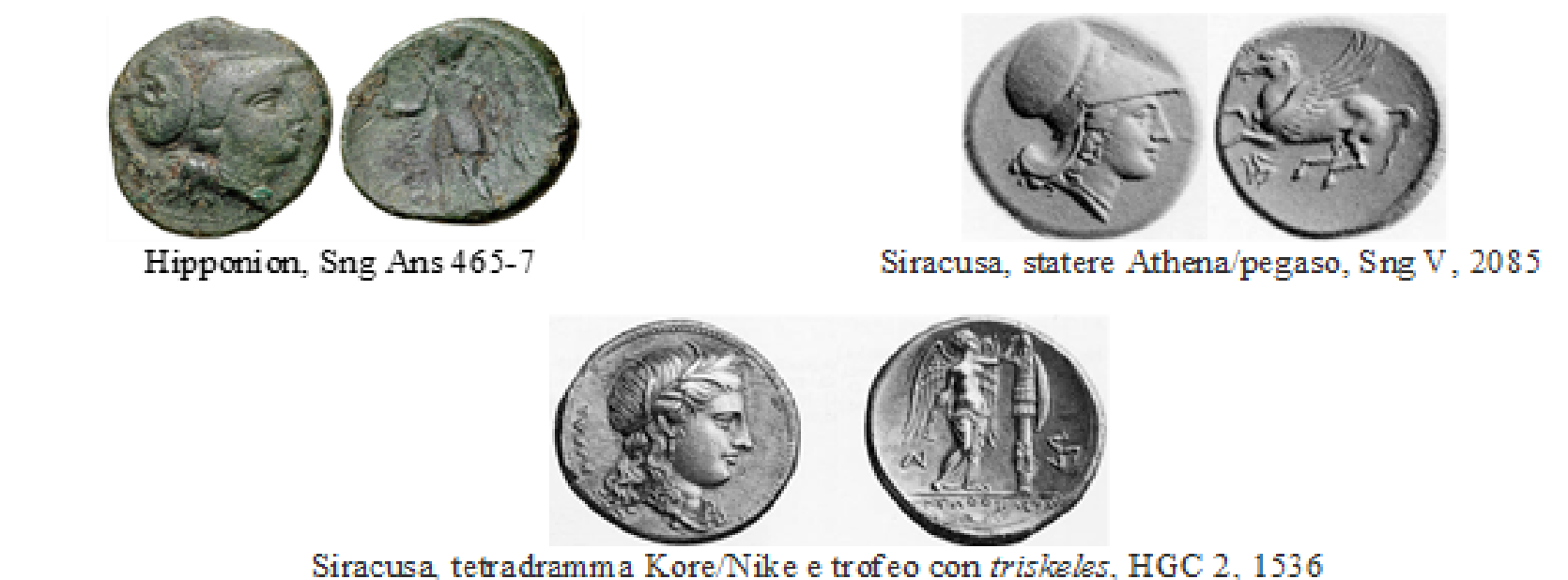

Siracusa, tetradramma Kore/Nike e trof eo con triskeles, HGC 2, 1536

Fig. 2. The Hipponion bronze imitates typically Agathoklean types, like the head of Athena with Corinthian helmet, and Nike.

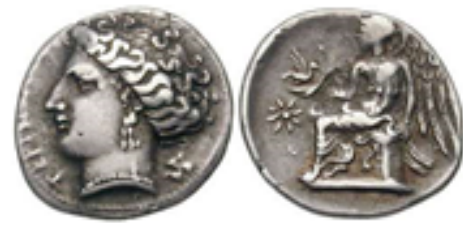

Terina, Sng Ans 867

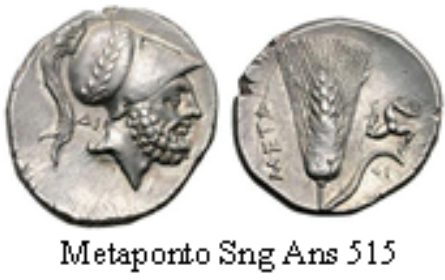

Metaponto Sng Ans 515

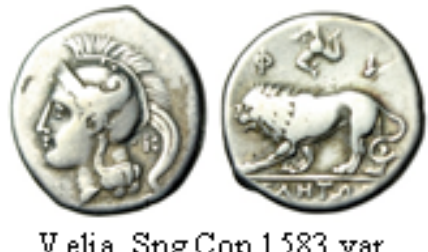

V elia, Sng Cop 1583 var.

Fig. 3. The triskeles appears on Terina, Metapontum and Velia coinage.

Agathokles assumed the basileia ${ }^{15}$. The reverse shows a winged, seated Nike, often compared with the Agathoklean Kore or Nike tetradrachms ${ }^{16}$.

Scholars also suggest an association between the Agathoklean pegasus and the Metapontum silver stater ${ }^{17}$, the obverse showing the head of Leucippus with Corinthian helmet and the typical Metapontum ear of barley on the reverse, flanked with the triskeles symbol, attributed by Johnston to the period $295-80 \mathrm{BC}^{18}$. It now seems that the series may be attributed to the Agathoklean period with certainty, also due to the presence of other symbols typical of the basileus, like the thunderbolt and the trophy, and the control marks that allow more precise dating ${ }^{19}$.

As for Velia, here too the silver staters with head of Athena in Attic helmet and crouching lion, have the triskeles on the reverse ${ }^{20}$. Precisely the presence of the triskeles on coins of the three cities is certainly of great interest. The iconographic association with Agathoklean coins, while not supported by other sources, should not be underestimated,

\footnotetext{
15 CACCAMO CALTABIANO 2010, 278. Scholars examine earlier interpretations of this symbol: starting with HILL 1903, 154, and SELTMAN 1912, 2, as well as BURNETT 1978, 92-120, and BÉREND 1998, 37-41, all saw the triskeles as a symbol of the power of Agathokles. WILSON 2003, 721-747 saw it as the expression of the Agathoklean ambitions of pan-Sicilian government, while BORBA FLORENZANO 2007, 153-157 saw it as the manifestation of "a regional identity as opposed to a local identity or polis identity", noting that only from the time of Agathokles' reign did the triskeles start "its course as the badge of Sicily".

16 See also SELTMAN 1912, 5, REGLING 1906, 55-57 and HILL 1903, 152153.

${ }^{17}$ CONSOLO LANGHER 2000, 312.

18 JOHNSTON 1985, 45-53.

19 CACCAMO CALTABIANO 2000, 33-42.

${ }^{20}$ CONSOLO LANGHER 2000, 312.
}

although it is not easy to determine the nature of the relationship with Syracuse. A similar description was inferred by Consolo Langher for Neapolis, Medma, Reggio, and Locri ${ }^{21}$. In particular, the influence of Syracuse on the southern area of Calabria at the time of Agathokles seems to be taken for granted by some authors and there are scholars who suggest, for instance, that Agathokles could not have conducted his operations in central-northern Bruttium if he had not already controlled the southern area.

This logical reasoning was not taken into account in particular with reference to Locri - by those who see the silence of literary sources to be crucial in confirming that Agathokles never exercised his authority over the polis ${ }^{22}$. Conversely, an analysis of numismatic documentation makes it possible to establish a very close link between Agathokles and Locri, as I have asserted elsewhere ${ }^{23}$.

Here, I will only point out the surprising connection between Agathoklean and Locri coinage, already obvious at a glance when observing various bronze series. The Athena-pegasus, Zeus-thunderbolt, Athena-thunderbolt, Artemis-thunderbolt series struck in Locri in circa $300 \mathrm{BC}$, when Agathokles began his military campaign in Bruttium, share complete type identification and stylistic affinity with corresponding Syracuse issue ${ }^{24}$.

\footnotetext{
21 See also CONSOLO LANGHER 2000, 313-314.

${ }^{22}$ In particular, in the intense debate regarding the identification of the basileus named on the Olympieion panels in Locri, lack of literary sources is also seen as strong proof for excluding Agathokles from the options. See DE FRANCISCIS 1972, 77 ff., VAN COMPERNOLLE 1987, 103-109.

${ }^{23}$ FILOCAMO 2009-2012, 115-155 and CASTRIZIO/FILOCAMO 2014 217-278.

${ }^{24}$ Some chronological doubts may arise about the Syracusan Zeus-thunderbolt series, at times attributed to the Agathoklean period (CALCIATI 1986, 283),
} 
SIRACUSA

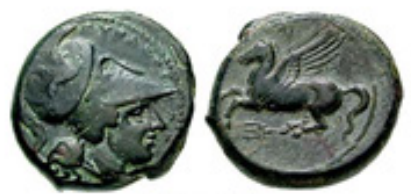

Sng ans 649

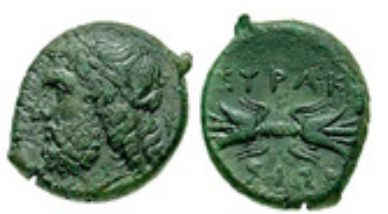

Calciati II 148 DS 59

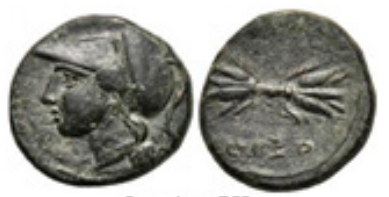

Sng Ans 752

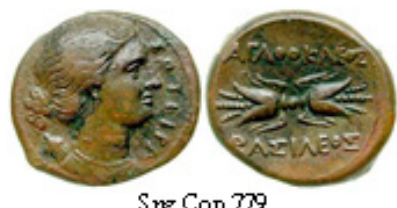

LOCRI

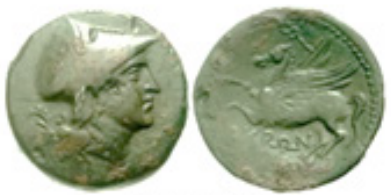

Sng Ars 573

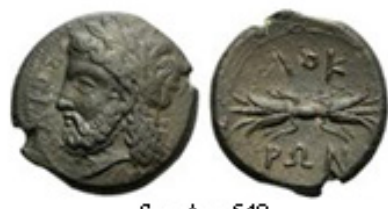

Srg Ars 540

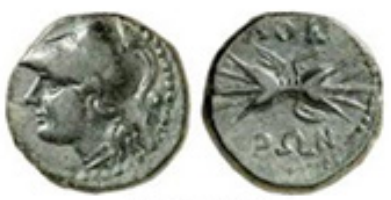

Sng Ars 545

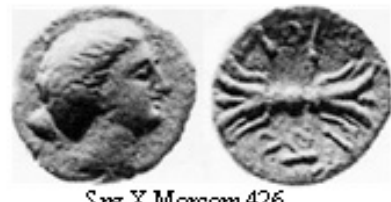

Sng X Morcom 426

Fig. 4. Comparing Syracuse and Locri, the type identification of the series reveals a close relationship between the two poleis in the Agathoklean period.
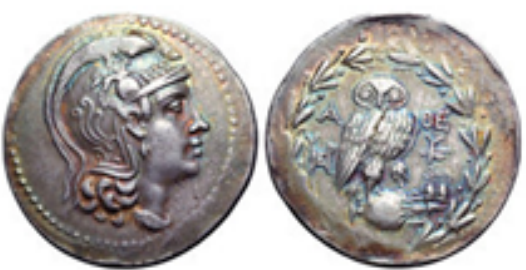

Atene, 154153 a.C. Thompson 61
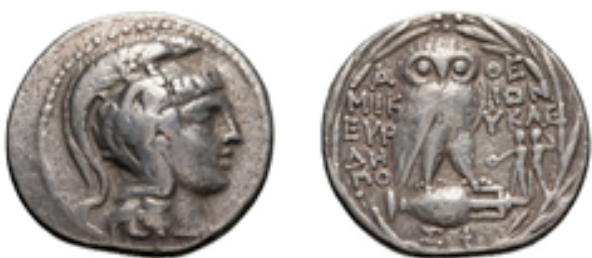

Atene, 124-123 a.C., Thompson 484 k-m

Fig. 5. Athenian tetradrachms in the New Style, or stephanephoroi.

If the influence exercised on Terina, Velia and Metapontum can be considered an interesting working hypothesis, such stringent comparisons for Locri should leave no doubt about the solid link existing between the city and Syracuse in the Agathoklean age. In the case of Locri, moreover, it is important to emphasize that coinage plays a pivotal role, not only in terms of iconography, but also for the information provided by the discovery data, the issue acronyms, and the weight system ${ }^{25}$, making coins a primary factor in the historical reconstruction of this phase of the Magna Graecia polis.

Agathokles exercised firm control over Locri and for this reason the city stayed away from military confrontations, which might explain why Diodorus does not speak of a

at others to the subsequent period (HEAD 1911, ROSS HOLLOWAY 1979, 87-95).

${ }^{25}$ CASTRIZIO/FILOCAMO 2014. relationship between Syracuse and Locri in his work, which is, in any case, fragmentary. In this instance, rather than an alliance, a hegemony exercised by Agathokles over Locri, and in all likelihood over many other Greek poleis, whose role may have been to forage Agathoklean garrisons, including the issue of currency. We should remember that precisely on the basis of numismatic documentation, Seltman suggested that the political and economic influence of Agathokles encompassed all Magna Graecia, as far as Neapolis and Cuma.

The case of the stephanephoroi of the second century $\mathrm{BC}$ is more challenging. As mentioned above, the name of these coins, also called New Style, comes from the fact that the classic owl type on the reverse of the Athenian tetradrachms of the period, coined on wide, thin rounds, is encircled by a laurel wreath ${ }^{26}$.

${ }^{26}$ According to DAREMBERG-SAGLIO 1887, see entry for Corona, the 


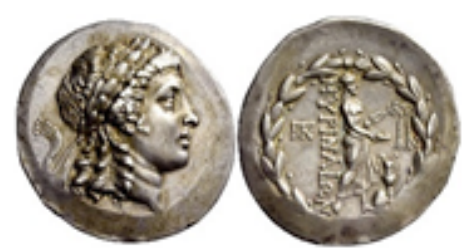

Myrina, SNG von Aulock 1665

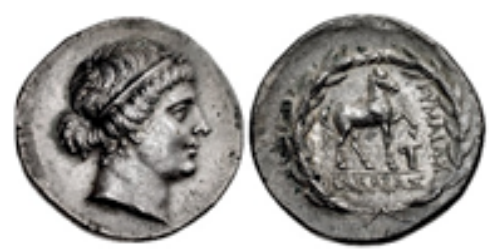

Cuma eolica, SNG vonAulock 1636

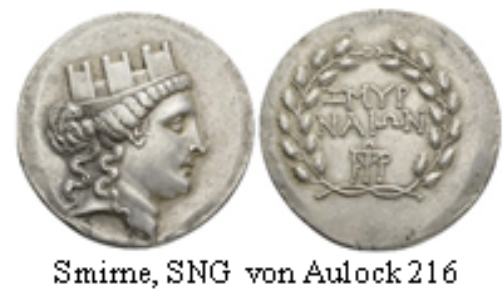

Smime, SNG von Aulock 216

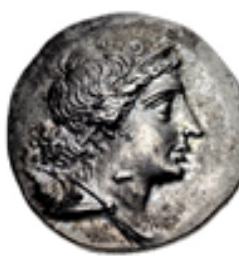

Magnesia sul Meandro, Sng von Aulock 2042

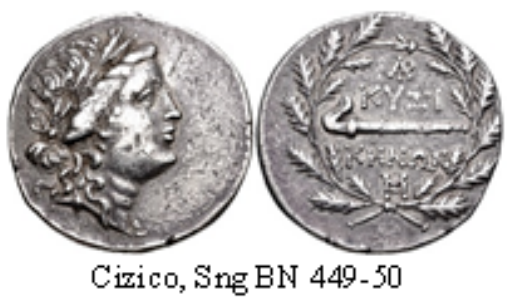

Cizico, Sng BN 449-50

Fig. 6. Examples of coins issued in the second century BC by poleis in Asia Minore, with the reverse showing a foliage crown.

Apart from these abundant issues, there are many from other poleis, particularly on the west coast of Asia Minor and beyond, with identical features, and which encircled their local type with a foliage crown. Of course, the problem arises of the iconographic connection with Athenian series in the New Style.

The questions raised by these issues are manifold and initially concerned precise dating, then the actual meaning of the crown, then the possibility that issuing cities were linked by some kind of economic, political or military alliance, which was precisely the significance of the crown.

In a 1961 landmark study, M. Thompson ${ }^{27}$ published a corpus of the Athenian series, starting dating from 198-7 $\mathrm{BC}$, connected to the release of the Greeks of Flamininus, and ending in $86 \mathrm{BC}$, following the Mithridatic War. Scholars examined thousands of coins, proposing a dating by year, thanks to information about the Athenian magistrates depicted.

The chronological sequence proposed by Thompson is largely still valid today, although the start and end dates have been challenged. A year later, in fact, Lewis pushed the beginning of the series to $164-3 \mathrm{BC}$, and the end to 50 $\mathrm{BC}$, for prosopographic reasons and following the analysis of coin treasure ${ }^{28}$, followed by H. Mattingly ${ }^{29}$. In 1984, O. Mørkholm proposed the years $185-80$ as a start date since he did not consider the nineteen issues prior to $145-4$ to be seamless, year by year, so it was possible to work back chronologically $^{30}$. On the other hand, Price and Mattingly ${ }^{31}$ confirmed Lewis's early dating based on the evidence of coin treasure, suggesting uninterrupted issues until $87 \mathrm{BC}$. Today this is the most popular theory ${ }^{32}$.

A number of explanations have been offered to explain the addition of the crown on coin types, not only in Athens, but in many other poleis in the Aegean area. Once we

stephane was a wide band worn on the forehead, while the stephanos indicated the foliage crown, the attribute of divinity. Nonetheless, stephanephoros is the term found in inscriptions. See MELVILLE JONES 1984, 218.

27 THOMPSON 1961.

${ }^{28}$ LEWIS 1962, 275-300.

${ }^{29}$ MATTINGLY 1969, 325-333

${ }^{30}$ MØRKHOLM 1984, 29-42.

${ }^{31}$ PRICE 1989, 233-243; MATTINGLY 1990, 67-78.

${ }^{32}$ ASHTON 2012, 191-209. accept the early dating of mid-160s BC, the first spontaneous link is to the conversion of Delos into a free port in $166 \mathrm{BC}$, subsequent to the Roman conquest of Macedonia in 168 BC, after the battle of Pydna. In fact, Rome left Athens control of Delos, which gradually replaced Rhodes in the Aegean as a commercial port. For this reason, Boehringer thought there may have been an economic alliance led by Athens and revolving around the port of Delos, whose stephanephoroi would have been common currency ${ }^{33}$. About twenty cities would have had their respective tetradrachms recognized as legal tender, with the characteristic crown. Robert rejected the arguments put forward by Boehringer, stating that it would have been very odd, among other things, that such a monetary union did not include cities such as Miletus, Ilios and Thassos, which did not have foliage crowns on their coins, while including Abydos, of which we have no news that proves it traded in the Aegean district, or with Athens and Delos ${ }^{34}$. He further claims that the ancient use of the term stephanephoroi refers only to Athenian coins, not that of other cities ${ }^{35}$. For his part, Giovannini sees a political motive in the minting of new coins, required by Rome to remind the Greek cities whom they had to thank for their freedom after Pydna ${ }^{36}$. Ashton recently cut the argument short, saying there are no good reasons to see these issues as some form of business, political or ideological alliance, and that it was simply a fad ${ }^{37}$.

For our part, we agree with the first of these two statements, regarding the impossibility of identifying a form of alliance among poleis through these coin issues, but at the same time we cannot believe it was just a fad. The custom of encircling the coin type within a foliage crown was already found in the Classical age, particularly in Magna Graecia and Sicily, and it has been observed that its arrival coincided in some poleis - Neapolis, Taras and Rhegion - with the fall of tyrants ${ }^{38}$. This perception was then taken explored,

33 BOHERINGER 1972, 31-39.

34 ROBERT 1977, 34-45.

35 Così già MELVILLE JONES 1973, 228.

36 GIOVANNINI 1978, 94-101.

37 ASHTON 2012, 199. See also LE RIDER 2001.

38 CACCAMO CALTABIANO 1993, 71. Again in this case, however, scholars consider the foliage crown merely a decorative element; see JENKINS 1970, 85; RUTTER 2001. 
underlining that the foliage crown appeared on coins at the time of major institutional changes, although the different local contexts may imply different symbolic meanings: religion, propaganda, politics ${ }^{39}$. Such an interpretation also fits well for the second century BC, whether we accept early dating (after Flamininus) or whether the later dating (after Pydna): reinstated freedom, real or perceived, was also celebrated on coins.

Accepting this view does not automatically lead to the exclusion of agreements of some kind to standardize issues among poleis. Nonetheless, in line with the most recent hermeneutics acquired, we are persuaded to see coinage as guided by the demands of public spending, rather than trade needs, and to favour a pragmatic rather than propagandistic approach when interpreting the decisions of the issuing authorities ${ }^{40}$. For this reason, the role of Rome cannot be considered marginal ${ }^{41}$. Consequently, when going back to the contributions of some of the scholars mentioned above, we feel it is possible to reconstruct the history of stephanephoroi thus: Athenian issues, probably subsequent to $168 \mathrm{BC}$, would have been characterized by stephane to celebrate political changes and reinstated freedom from the Macedonians, paying homage to the new masters, who entrusted Athens with the management of the port of Delos; the amount of coinage was remarkable, having to replace the Macedonian Alexanders. Rome gave the cities under its control monetary autonomy, for example in the choice of the type, but intervened on issues for its expenditure requirements, especially for military needs, as seems to be indicated by the abundant issues of certain years (126-3 BC), found in coin treasures in the northern Aegean and earmarked for the payment of garrisons stationed in Macedonia ${ }^{42}$. Delos coin treasures, which were also of remarkable amounts, may also be explained in the context of warfare, including the looting of Mithridates in 88 and 69 BC. Moreover, it should certainly not surprise that a trading city like Delos attracted money, but this does not mean that issues with a crown were struck for commercial reasons. As for the other poleis, it may be that the stephane was simply an imitative process, which might have had the advantage of coins being more acceptable abroad, particularly in Syria, in terms of exchange rate ${ }^{43}$. This would explain the abundant finds of coins with crown in Myrina, Heraclea and Lebedus in Seleucid territory, hardly compatible with an issue for trade, and usually connected to funds given to Alexander Balas by the Attalids to fight Demetrius of Syria between 153 and 145 BC $^{44}$.

In this case, therefore, the adoption of a similar iconographic motif for coins of different cities suggests no sort of political or economic alliance. Athens used it to herald a new political phase, celebrating the recovery of freedom, but which actually meant submission to new, probably more acceptable lords. The spread of the Athenian stephanephoroi persuaded other poleis to mimic the features in their own coinage systems because it was better accepted outside city territory, and the iconographic elements would also be

\footnotetext{
${ }_{39}$ SPINELLI 2010, 3, 59-70.

${ }^{40}$ DE CALLATAY 2011, 55-86.

${ }^{41}$ See also DE CALLATAY 2011

42 DE CALLATAY 2011, 70

${ }^{43}$ LE RIDER 2001, 53-56.

${ }^{44}$ KINNS 1987, 107; HOOVER/MACDONALD 1999-2000, 109-117.
}

useful for immediate recognition.

Completely different, and not just for context, the case of the nineteenth-century Latin Union, founded in 1865 by France, Belgium, Switzerland and Italy; Greece joined later, in 1868, while many other countries, even outside Europe, adapted spontaneously without officially being members ${ }^{45}$. The agreements provided for uniform coinage among member countries, which had already espoused the same bimetallic system, modelled on the French gold-silver concept. The fluctuation in the market value of the precious metals, however, led to a difference between one state and another, in the fineness of silver coins that had the same face value. The Treaty of 23 December 1865 established the amount of silver to be used in the coins, the weight, tolerance, etc. We will not discuss in detail the agreements within a union that saw France as the hegemonic power and which, through a series of tacit or expressed modifications and renewals, lasted until 1926, but which actually first deteriorated and was then voided of importance as early as 1870 s and $1880 s^{46}$. Here we are interested in the iconographic aspect, which nevertheless has a more limited function than in the past, perhaps even for the availability of other means for conveying propaganda messages. In Italy, coinage of the post-Unification period certainly paid far more limited attention to iconography than it did in the immediately prior Risorgimento period, when even coin types propagated messages of freedom and change ${ }^{47}$. Political unification was followed by a monetary union and led to the adoption of Piedmontese types, with the crest of the House of Savoy. The 1862 law established that all coins should bear the image of the King and the legend of the Kingdom and King of Italy ${ }^{48}$. Even before the end of the Latin Union, a decree had given legal tender status to gold and silver coins in France and Belgium $^{49}$. The 1865 agreements governed minting (see Art. 1 of the 1865 Convention) so that weight, fineness, diameter, and circulation of the coins minted in gold and silver, but nothing was said with respect to the type, which could thus be freely chosen.

We are of the opinion that silence on this aspect could give rise to two types of problems. One related to the recognition of the coins by a population suffering - at least in Italy - from a high rate of illiteracy ${ }^{50}$ : how would an Italian citizen who could not read and write, recognize and accept payment of Swiss or Belgian currency? Delegates of the member states do not appear to have concerned themselves with the issue which, moreover, would have arisen regardless of the Latin Union, since the Law of 1862 already made it possible to grant legal tender status to a number of foreign currencies corresponding to Italian coins, which did occur. Moreover, to some extent it may possibly already have occurred precisely with national monetary unification and the Piedmontese lira, when, to achieve gradual replacement

\footnotetext{
${ }^{45}$ For a history of the Union see, among others, WILLIS 1901, MARCONCINI 1929. For the most recent works, DE CECCO 1996, 57-67, EINAUDI 2001. 46 See PECORARI 1999.

47 CARROCCIO 2014, 561-583.

48 Art. 8 of Law 788 applicable to the unification of the monetary system, 24 August 1862 .

${ }^{49}$ CARBONERI 1915, 305.

${ }^{50}$ In 1871 , over two-thirds of Italians were illiterate, with peaks of $86 \%$ in the
} south of the country. See VECCHI 2011, 425-426. 

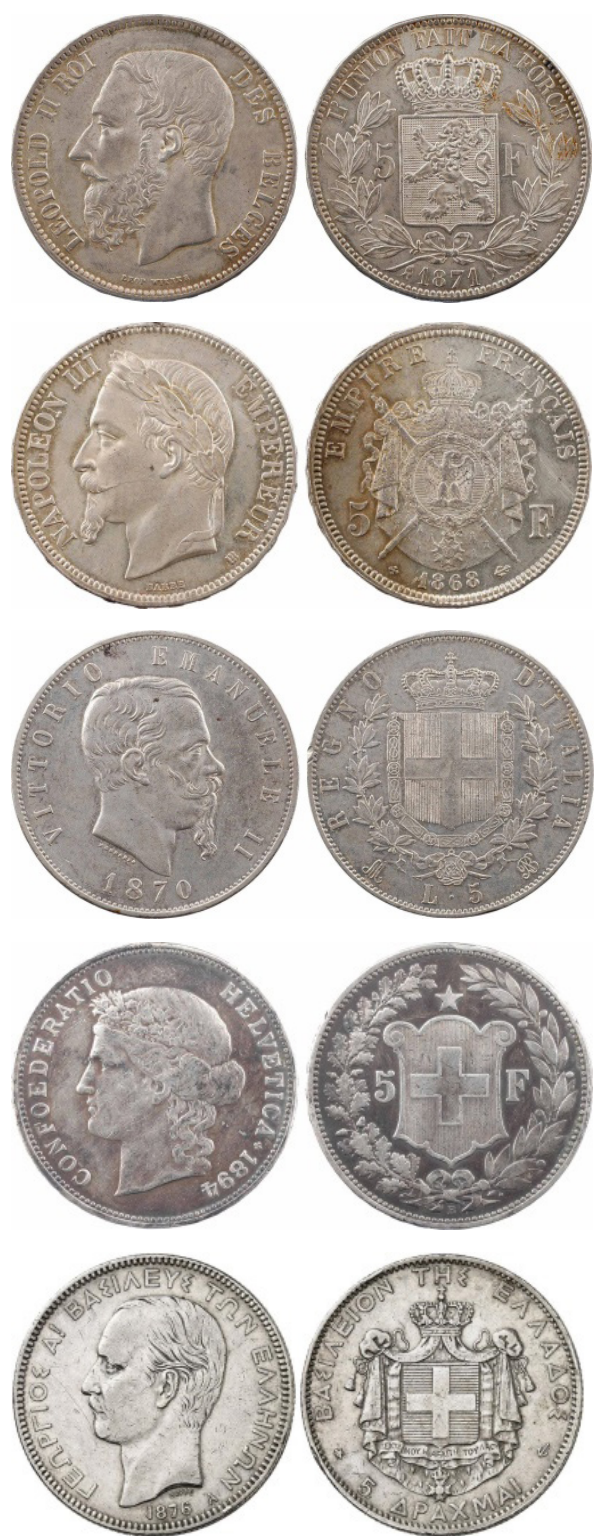

with new coins, pre-Unification currencies were temporarily left in circulation, so it took many years to actually complete the changeover. The second problem concerned the possibility of falsification, a risk that increased making legal tender of foreign currencies that much of the population could not recognize. The problem appears to have been merely touched upon in the sessions leading up to the 1865 Convention. The President of the Conference, France's Parieu, expressed his views on the subject in the second session ${ }^{51}$, saying he wanted coins to be minted in the countries of the Union with special identification marks, but this was precluded by the fact that Italy, in particular, had just issued a large amount of currency, precisely as a consequence of the Unification. The withdrawal and recasting of coins for new coinage would have been too expensive, so the decision was simply regulation of diameter, weight, fineness, and tolerance, using Italy's currency as a model, and leaving freedom for type. Understandably, practical and economic considerations took precedence over any ideological notion. The problem of counterfeiting arose once more at the 1876 Conference $^{52}$, but the approach was essentially technical: every country

\footnotetext{
51 See Convention monétaire 1865, 555.
}

52 Conférence monétaire 1876, 13. had to guarantee maximum accuracy when complying with coin weight and fineness regulations. From the external point of view, the only request made was specifically for Italy, required to emboss the legend on coins, but the final declaration merely provided for communication between member states of relevant facts with regard to counterfeiting of coins and to agree on any common measures to be taken.

A glance at the coinage of the member states of the Latin Union will reveal some similarities ${ }^{53}$, like portraying the ruler on the obverse of a coin (for Switzerland, the personification of the Swiss nation) and the crest on the reverse. In Greece, King George of Denmark changed the monetary system to adopt that of the Latin Union in 1867, but the country did not mint its own coins until $1876^{54}$, and in the absence of information concerning the exterior, the coins showed the King's portrait on the obverse and the crest of the Kingdom on the reverse.

However, there is a similarity that can be ascribed to the Union, given that the types do not change after 1865 , as mentioned above, but we can assume that this is at least to some extent the consequence of another attempt at ${ }_{53}$ We consider silver écus here, worth 5 francs, which may represent the symbolic coins of the Latin Union, as unique pieces of purest silver.

${ }^{54}$ Conférence monétaire 1876, 13. 
unification, dating back about to about sixty years earlier. The Latin Union monetary system was inspired by the French bimetallic concept developed at the time of Napoleon Bonaparte, who was keen to have similar coinage circulating in his empire. We know from a letter (published by Parieu precisely in 1871) addressed to his brothers, who reigned in Naples and in the Netherlands, that the Emperor wished the coins to bear the portrait of the sovereign on one side and the crest of the kingdom on the other, as he had already devised for the Kingdom of Italy. The original text stated: ${ }^{55}$.

My brother,

If you do strike coins, I would like you to adopt the same divisions of value as the coins in France, and that your coins bear your likeness on one side and on the other the crest of your kingdom. I have already done this for the Kingdom of Italy. The confederate princes are doing the same. In this way, there will be uniformity of coinage throughout Europe, which will be a great advantage for trade. There should be no problem in adding a legend stating the value of the coin, for example, Napoleon of 20 francs, etc.

Finkenstein, May 6, 1807.

We may conclude that the iconographic aspect was actually marginal within the Latin Union, where there were no outward signs on coins to identify an alliance. At most, there was resort to reproduction of the portrait of the sovereign and kingdom's crest, consolidated under Napoleonic rule, a custom that would contribute to giving a touch of familiarity to coins, without supposing there was any particular propaganda message. The indication of the value and the physical characteristics of the coins, in particular the diameter, would have been enough to allow citizens to recognize and accept them.

Conversely, the few indications that can be drawn from the minutes of the meetings for drafting agreements tend to focus on national identity rather than on the alliance. Apart from the aforementioned intervention by Parieu, stating that adding marks on coins to identify the Union was not required because of the cost, it was during the 1876 meeting for the review of several rules that the situation of Greece (which had just started minting its own coins) was examined. President Dumas then stated how it was natural for each state to have its own national currency whose exterior would show its independence, a tangible and sensitive sign of nationality, a political necessity of a higher order. $^{56}$

If we are to compare this with the current European Monetary Union, today's metal coins show a standard side, with an image of Europe that symbolizes the cohesion among the EU member states; the other side is left to the individual country. Despite some propagandistic effort, ${ }^{57}$ however, it does not seem that the message reached citizens forcefully, and for the most part it is likely that they do not remember or even recognize the types imprinted on coins. Similar considerations apply to notes, where the windows, portals ${ }_{55}$ DE PARIEU 1871.

56 Conférence monétaire 1876, 75-76.

57 In Italy, for example, after a commission selected a number of images from the greatest Italian masterpieces, the final choice was left to the general public, during a national television broadcast. and bridges depicted on them are meant to symbolize the openness, collaboration and dialogue that inspire the peoples of Europe. All principles, if I may be allowed a polemic note, which in reality have remained on paper, judging from the situation now facing the Eurozone.

\section{REFERENCES}

\section{ASHTON 2012}

Ashton, R., The Hellenistic World: the Cities of Mainland Greece and Asia Minor. In: Metcalf, W. E. (ed.), The Oxford Handbook of Greek and Roman Coinage (Oxford: Oxford University Press), 191-209.

BÉREND 1998

Bérend, D., De l'or d'Agathocle. In:Ashton, R./Hurter, S. (eds.), Studies in Greek Numismatics in Memory of M. J. Price (London: Spink \& Son Ltd).

\section{BOHERINGER 1972}

Boheringer, C., Zur Chronologie mittelhellenistischer Münzserien, 220-160 v. Chr. (Berlin: De Gruyter).

BORBA FLORENZANO 2007

Borba Florenzano, M. B. A Note on the Triskeles as the Badge of Sicily: Territorial Identity in Ancient Greek Coinage. In: Moucharte G./Borba Florenzano, M. B./De Callatay, F./ Marchetti, P./Smolderen, L./Yannopoulos, P. (eds.), Liber Amicorum Tony Hackens (Louvain La Neuve: Association de numismatique professeur Marcel Hoc).

BRACCESI 1977

Braccesi, L., Grecità adriatica. Un capitolo della colonizzazione greca in Occidente (Bologna: Pàtron).

BURNETT 1978

Burnett, A., The Coinage of Rome and Magna Grecia in the late fourth and third century B.C., Revue Suisse de Numismatique 57, 92-120.

CACCAMO CALTABIANO 1993

Caccamo Caltabiano, M., La monetazione di Messana. Con le emissioni di Rhegion dell'età della tirannide, (Berlin-New York: De Gruyter).

CACCAMO CALTABIANO 2000

Caccamo Caltabiano, M., Le monete di Metaponto e l'influenza di Agatocle. In: Hurter, S./Arnold-Biucchi, C. (eds.), Pour Denyse, Divertissement Numismatiques (Bern: Dr. Schüler), 33-42.

\section{CACCAMO CALTABIANO 2010}

Caccamo Caltabiano, M., La Nike/Nymphe di Agatocle e l'ideologia della Vittoria. In: Caccamo Caltabiano, M./ Raccuia, C./Santagati E. (eds.), Tyrannis, Basileia, Imperium. Forme prassi e simboli del potere politico nel mondo greco e romano. Giornate seminariali in onore di S. Consolo Langher (Messina 17-19 Dicembre 2007), Pelorias 18 (Messina: Di.Sc.A.M.).

\section{CALCIATI 1986}

Calciati, R., Corpus Nummorum Siculorum II, (Pieve del Cairo-Milano: Ed. G. M.).

\section{CARBONERI 1915}

Carboneri, G., La circolazione monetaria nei diversi Stati, I, Monete e biglietti in Italia dalla Rivoluzione Francese ai nostri giorni (Roma: Tip dell'Unione Editrice).

CARROCCIO 2014

Carroccio, B., Le monete patriottiche nel secolo delle rivoluzioni tra bisogno, propaganda e antichi richiami. In: De Sensi, G./Petrusewicz, M. (eds.), Unità multiple. Centocinquant'anni? Unità? Italia? (Soveria Mannelli: Rubbettino), 561-583.

CASTRIZIO/FILOCAMO 2014

Castrizio, D./Filocamo, A., Agatocle e l'archivio locrese di Zeus Olimpio. Un approccio numismatico, Revue Belge de 
Numismatique et de Sigillographie CLX, 217-278.

Conférence monétaire 1876

Ministère des Affaires Étrangères, Conférence monétaire entre la Belgique, la France, l'Italie et la Suisse. Procès verbaux (Paris: Imprimerie nationale).

CONSOLO LANGHER 2000

Consolo Langher, S. N., Agatocle. Da capoparte a monarca fondatore di un regno tra Cartagine e i Diadochi (Messina: DiScAM).

Convention monétaire 1865

Belgique, France, Italie, Suisse. Convention monétaire, signée à Paris, le 23 dicembre 1865. Procès verbaux des Conférences. In: Archives diplomatiques: recueil de diplomatie et d'histoire II, 27 (Paris).

DAREMBERG/SAGLIO 1887

Daremberg, C./Saglio, E., Dictionnaire des Antiquités Grecques et Romaines (Paris: Hachette), s.v. Corona.

DE CALLATAY 2011

De Callatay, F., More than it would seem: The Use of Coinage by the Romans in Late Hellenistic Asia Minor (113-63 a. C.), American Journal of Numismatic 23, 55-86.

DE CECCO 1996

De Cecco, M., L'Unione Monetaria Europea: insegnamenti dell'esperienza storica, Moneta e credito 49, 193, 57-67.

DE FRANCISCIS 1972

De Franciscis, A., Stato e società in Locri Epizefiri (Napoli: Libreria scientifica).

DE PARIEU 1871

De Parieu, F. E, La question de l'unification monétaire en 1870, Journal des économistes, 15 mai 1871.

DE SANCTIS 1909

De Sanctis, G. Agatocle. In: De Sanctis, G. (ed.), Per la scienza dell'antichità (Torino: Bocca).

EINAUDI 2001

Einaudi, L., Money and Politics. European Monetary Unification and the International Gold Standard (1865-1973) (New York: Oxford University Press).

FILOCAMO 2009-2012

Filocamo, A., Locri Epizefiri: l'archivio di Zeus e la monetazione, Minima Epigraphica et Papyrologica XII$\mathrm{XV} / 14-17,115-155$.

GARGANO 2012

Gargano, G., Vibo Valentia/Hipponion, sezione A: Fonti numismatiche. In: Bibliografia Topografica della Colonizzazione Greca in Italia e nelle Isole Tirreniche XXI. Siti, Torre Castelluccia-Zambrone (Pisa-Roma-Napoli).

GIOVANNINI 1978

Giovannini, A. Rome et la circulation monétaire en Grèce au IIe HEAD 1911 siècle avant Jésus-Christ (Basle: F. Reinhardt).

Head, B. V., Historia Numorun. A manual of Greek Numismatic HILL 1903 (Oxford: Clarendon Press).

Hill, G.L. Coins of ancient Sicily (Westminster: A. Constable $\&$ Co.).

HOOVER/MACDONALD 1999-2000

Hoover, O./MacDonald, D., Syrian Imitations of New Style Athenian tetradrachms struck over Myrina, Berytos 44, 109-117.

JENKINS 1970

Jenkins, G. K., The coinage of Gela, (Berlin: De Gruyter).

JOHNSTON 1985

Johnston, A., Report of a discussion on South Italian KINNS 1987 Chronology, 350-280 B. C., Coins Hoards VII, 45-53.

Kinns, P. Asia Minor. In: Burnett, A. M./Crawford, M. (eds.),
The Coinage of the Roman World in the Late Republic (Oxford: BAR).

LE RIDER 2001

Le Rider, G. Sur un aspect de comportement monétaire des villes libres d'Asie Mineure occidentale au IIe siècle a.C. In: Bresson, A./Descat, R. (eds.), Les cités d'Asie MIneure occidentale au IIe siècle a.C. (Bordeaux: Ausonius).

\section{LEWIS 1962}

Lewis, D. M., The Chronology of the Athenian New Style Coinage, The Numismatic Chronicle 2, 275-300.

\section{MARASCO 1984}

Marasco, G., Agatocle e la politica siracusana agli inizi del III sec. a. C., Prometheus 10, 97-113.

\section{MARCONCINI 1929}

Marconcini, F., Vicende dell'oro e dell'argento. Dalle premesse storiche alla liquidazione dell'Unione Monetaria Latina (18031925) (Milano: Società editrice "Vita e pensiero").

\section{MATTINGLY 1969}

Mattingly, H., Review of M. Thompson, the Agrinion Hoard, The Numismatic Chronicle, 9, 325-333.

MATTINGLY 1990

Mattingly, H., The Beginning of the New Style Silver Coinage, The Numismatic Chronicle 150, 67-78.

MELVILLE JONES 1973

Melville Jones, J. R., Book Review: Boehringer, C., Zur Chronologie mittelhelenistischer Münzserien 220-160 v. Chr. (Antike Münzen und geschnittene Steine, Band v), The Numismatic Chronicle 13, 226-229.

MELVILLE JONES 1984

Melville Jones, J. R., Dictionary of Ancient Greek Coins (London: Seaby).

MØRKHOLM 1984

Mørkholm, O., The Chronology of the New Style Coinage of Athens, Museum Notes. American Numismatic Society 29, 29-42.

\section{PECORARI 1999}

Pecorari, P., La lira debole. L'Italia, l'Unione Monetaria latina e PRICE 1989 il "bimetallismo zoppo" (Padova: CEDAM).

Price, M. J., The Larissa, 1968 Hoard (IGCH 237). In: Le Rider, G./Jenkins, K./Waggoner, N./Westermark, U. (eds.), Kraay-Mørkholm Essays (Louvain-la-Neuve: Institut supérieur d'archéologie et d'histoire de l'art, Séminaire de numismatique Marcel Hoc), 233-243.

\section{REGLING 1906}

Regling, K. Terina (Berlin: G. Reimer).

\section{ROBERT 1977}

Robert, L. Monnaie Hellénistiques, Revue Numismatique 6, 19, 34-45.

\section{ROSS HOLLOWAY 1979}

Ross Holloway, R. The Bronze Coinage of Agathocles. In: Thompson; M./Mørkholm, O./Waggoner, N. (eds.), Greek Numismatics and Archaeology. Essays in honor of M. Thompson (Wetteren), 87-95.

\section{RUTTER 2001}

Rutter, N. K., Historia Nummorum. Italy (London: The British Museum Press).

\section{SELTMAN 1912}

Seltman, C. T., The influence of Agathokles on the Coinage of Magna Grecia, The Numismatic Chronicle 4a serie, 12, 7 ss.

\section{SPINELLI 2010}

Spinelli, M., Per un Lexicon Iconographicum Numismaticae. Le stephanophoroi di età classica, Polis. Studi interdisciplinari sul mondo antico III/3, 59-70.

TALIERCIO MENSITIERI 1993

Taliercio Mensitieri, M. Problemi monetari di Hipponion e 
delle città della Brettia tra IV e III sec. a.C.. In: Crotone e la sua storia tra IV e III sec. a.C., Atti del Seminario Internazionale, Napoli 1987 (Napoli), 131-186.

THOMPSON 1961

Thompson, M., The New Style Silver Coinage of Athens (New York: American Numismatic Soc.)

TROXELL 1975

Troxell, H. A., Sylloge Nummorum Graecorum. The Collection of the American Numismatic Society, Sicily III, Syracuse-Siceliotes (New York: The American Numismatic Society).

VAN COMPERNOLLE 1987

Van Compernolle, R., Agathoklès de Syracuse et Locres Epizéphyrienne. In: Studia Varia Bruxellensia (Leuven: Peeters), 103-109.

\section{VECCHI 2011}

Vecchi, G., In ricchezza e in povertà. Il benessere degli italiani dall'Unità ad oggi (Bologna: $\underline{\text { Il Mulino). }}$.

\section{WILLIS 1901}

Willis, H. P., A History of the Latin Monetary Union (Chicago: Chicago Press).

\section{WILSON 2003}

Wilson, R. J. A., From Palma di Montichiaro to the Isle of Man: the use of the triskeles in Antiquity and after. In: Fiorentini G./Caltabiano, M./Calderone A., Archeologia del Mediterraneo. Studi in onore di E. De Miro (Roma: L’Erma di Bretschneider), 721-747. 